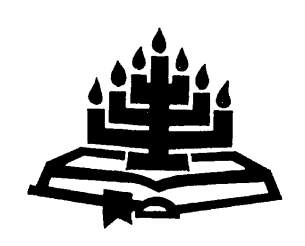

\title{
Die keuse van 'n model vir inhoudsanalise van preke oor armoede en aan armes as hoorders $^{1}$
}

\author{
H.J.C. Pieterse \\ Praktiese Teologie \\ Universiteit van Pretoria \\ PRETORIA \\ E-pos: pietehjc@absamail.co.za
}

\begin{abstract}
A model for content analysis of sermons on poverty and to the poor as listeners
\end{abstract}

The argument in this article is that the leading research question for content analysis of sermons has an influence on the choice of a model for research analysis. The author is searching for a suitable model for sermon analysis in order to analyse sermons on poverty and those directed to the poor. Different authors worked in this field of research, e.g. Cilliers (1982), Pieterse (1986; 1995a; 1995b), Moehn (1996), Vaessen (1997), Stark (2005), De Klerk et al. (2009) and Immink \& Verweij (2007). The following models of content analysis for sermons are discussed: the Heidelberg model, the Heidelberg model with the use of the Kwalitan computer programme, the hermeneutical model developed by Vaessen, the model for researching the sermon as a Word of God by Stark, this combination of the Heidelberg model and Stark's model by De Klerk, De Wet and Letšosa, and the grounded theory model for inductive analsysis of sermons in order to develop a theory from the data. The research question of the author's project, namely on how preachers deal with sermons on poverty and those directed to the poor, has lead him to the choice for a grounded theory model developed by colleagues in Utrecht, the Netherlands.

1 Die artikel is deel van 'n projek met finansiële steun van die National Research Foundation. 


\section{Opsomming}

\section{'n Model vir inhoudsanalise van preke oor armoede en aan armes as hoorders}

In hierdie artikel word geargumenteer dat die navorsingsvraag wat die inhoudsanalise van preke begelei, die keuse van 'n model vir die analise beïnvloed. Die outeur is op soek na 'n gepaste model vir preekanalise om preke oor armoede en aan armes as hoorders te analiseer. Verskillende outeurs het in hierdie ondersoekveld gepubliseer, byvoorbeeld Cilliers (1982), Pieterse (1986; 1995a; 1995b), Moehn (1996), Vaessen (1997), Stark (2005), De Klerk et al. (2009) en Immink \& Verweij (2007). Die volgende modelle vir preekanalises word bespreek: die Heidelbergse model, die versterking van die Heidelbergse model deur gebruikmaking van die Kwalitan-rekenaarprogram, die hermeneutiese model wat deur Vaessen ontwikkel is, die model vir die vasstelling van prediking as Woord van God deur Stark, die kombinasie van die Heidelbergse model met die model van Stark deur De Klerk, De Wet en Letšosa en die "grounded theory"-model wat induktief vanuit die preke self 'n preekteorie ontwikkel. Die navorsingsvraag van die outeur se projek van preekanalises van preke oor armoede en aan armes lei hom tot die keuse van die "grounded theory"-model soos dit deur kollegas in Utrecht, Nederland, ontwikkel is.

\section{Inleiding}

Dit is 'n voorreg om 'n bydrae te lewer by die emiritaatsaanvaarding van professor Ben de Klerk. Hy het 'n groot bydrae tot die teologie in die algemeen en die praktiese teologie in die besonder gemaak. Nie alleen is hy 'n kenner van formaat van die liturgiek nie, maar ook 'n uitmuntende eksegeet, wat ook uit sy werk oor die homiletiek blyk. As enkele voorbeelde kan 'n mens slegs kyk na sy grondige en fynsinnige artikel oor 'n klein element in die erediens, naamlik die seën (De Klerk, 2007) en sy fundamentele insigte in die prediking (De Klerk \& Janse van Rensburg, 2005). Hierdie bydrae van hom tot die vak is ook gedra deur ' $n$ aangename en samewerkende persoonlikheid. Hierdie artikel sluit aan by die jongste werk van De Klerk en sy kollegas, naamlik inhoudsanalise van preke (vgl. De Klerk \& De Wet, 2008; De Klerk et al., 2009).

Die oorhoofse vraagstelling van hierdie ondersoek lui: Hoe hanteer predikers hulle prediking oor armoede en aan armes met die koninkryksgelykenisse van Jesus as teks? (vgl. Pieterse, 2009). Die vraag in hierdie artikel is: watter model van die preekanalise sal pas op my spesifieke vraag, wat impliseer dat die verstaan van 'n konin- 
kryksgelykenis as teks én die armoedesituasie waardeur die verkondiging gerig word, uit die preek self gedelf moet word - dus 'n begripsvorming van onder af. Moontlik kan 'n mens 'n teorie vorm uit die preekmateriaal, wat dan weer aan teologiese kritiek blootgestel kan word. Dit is belangrik om 'n gepaste model van inhoudsanalise te vind vir die spesifieke vraagstelling en benadering tot die preekanalise waarmee ' $n$ mens besig is. Die doel in hierdie artikel met die behandeling van verskillende inhoudsanalises van preke deur kollegas is naamlik om vas te stel hoe hulle vraagstelling die keuse van analisemodelle beïnvloed het. Dit word algemeen aanvaar in navorsingskringe dat jou vraagstelling deurslaggewend is vir jou benadering of model van ondersoek en die uitkoms van die navorsing. Daarom is die argument van hierdie artikel dat die vraagstelling van die ondersoek wat 'n mens wil doen in die inhoudsanalise van preke eintlik bepaal watter model van analise gekies word. In die bespreking van 'n paar ondersoeke en die modelle van inhoudsanalise wat gebruik is, sal hierdie uitgangspunt duidelik word.

Volgens Grözinger (2008:299-300) is daar drie perspektiewe waarvolgens preekanalises gedoen kan word. Dit is analises met die oog op die persoon van die prediker en die invloed daarvan op die preek. Die tweede perspektief het te make met analises wat vra na die taal van die preek. Die derde perspektief is ondersoek na die inhoud van die preek - dus inhoudsanalises. In ons tyd, sê Grözinger, is inhoudsanalises belangrik vanweë die pluraliteit van spiritualiteite en kontekste in die samelewing (Grözinger, 2008:300). Die modelle wat in hierdie artikel aan die bod kom, het almal te make met inhoudsanalise van preke. By inhoudsanalise word geskrewe preke gewoonlik gebruik (vgl. Cilliers, 1982:11). Die bedoeling in my ondersoek na prediking oor armoede en aan armes as hoorders is om slegs geskrewe preke te analiseer. Prediking is optrede en die hoorders is betrokke by die interpretasie van die preek soos die resepsie-estetika leer (Cilliers, 1994). Daarom behoort die hoorders van die preek met onderhoude oor hulle verstaan van die preek ondersoek te word. Die konteks van die liturgie speel ook 'n rol (vgl. Moehn, 1996:2-17). Deur slegs inhoudsanalise van geskrewe preke of getikte preke van bandopnames te analiseer, plaas 'n beperking op die ondersoek. Tog het die inhoudsanalise van geskrewe preke voordele. Wat die prediker werklik sê, watter teologie en eksegese gebruik is, die konteks van die gemeente en hoe hy dit hanteer, ensovoorts kan taamlik betroubaar opgespoor word. Verder is die inhoudsanalise nie deel van die kommunikasieproses in die erediens nie. Op hierdie wyse beïnvloed dit nie die inhoud van die boodskap 
of die proses van kommunikasie deur die navorser se teenwoordigheid nie.

\section{Teologiese vertrekpunt}

Dit is belangrik om sketsmatig my teologiese siening oor die prediking aan te stip, omdat geen mens op 'n absoluut objektiewe manier preke kan analiseer en interpreteer nie, selfs al soek jy na die begrippe in die preek soos dit hulself aanbied - dus 'n induktiewe benadering. Die teologiese teorie waarbinne jy dink, funksioneer altyd, ook as 'n mens met beginbegrippe (sensitising concepts) in die grounded theory-benadering werk (vgl. Kelle, 2005). In hierdie ondersoek word gewerk met 'n teologiese vertrekpunt rakende die prediking binne die gereformeerde teologiese tradisie. Binne die praktiese teologie in hierdie tradisie word vir hierdie ondersoek aangesluit by Immink (2003) wat dit sien as 'n studie van die geloofspraktyk van mense wat in God glo. Christelike geloofspraktyk impliseer 'n eksistensiële geloofsverhouding tussen God en mense waarin God tot sy volle reg kom en mense voluit as mense tot hulle reg kom (Immink, 2003:18-19).

Die Bybelskrywers is geïnspireer deur die Heilige Gees om die openbarende handelinge van God met woord en daad in die heilsgeskiedenis van Israel op te teken. Hierdie openbarende handelinge van God in die geskiedenis loop uit op die volledige en finale openbaring in die lewe, sterwe en opstanding van Jesus Christus. In die Skrif vind die prediker dus die geïnspireerde Woord van God wat die bron van die blye Bybelse boodskap is (vgl. 2 Pet. 1:21; 2 Tim. $3: 16)$. Prediking is prediking van die Woord van God. Die Heilige Gees was die Inspirator van die Bybelskrywers en is vir die biddende leser en interpreteerder van die Skrifwoorde vandag die Illuminator. Uit hierdie insig vloei die organiese inspirasieleer voort en dit bewaar ons van fundamentalisme in die verstaan van die Skrif. Die troos vir die prediker is dat dieselfde Gees vandag ons hart en verstand verlig om die Bybelse woorde te verstaan soos die Gees dit bedoel. Die werking van die Heilige Gees is die voorwaarde vir ons verstaan van die Skrif, vir die proses van preekvoorbereiding en die prediking in die erediens.

Die preek geskied in die sentrum van die erediensgebeure. Daarom word die preek gesien as deel van die erediensgebeure en is dit so dat die Heilige Gees wyer as net die Skriflesing en die preek werksaam is. Ons bely die teenwoordigheid van Christus in die erediensgebeure en in die preekgebeure. Hy is teenwoordig deur sy Woord en sy Gees. Die memoria Christi, die herinnering aan die 
heilsdade van Jesus, en aan Homself as opgestane Heer, is die eerste vereiste vir die belewing van sy lewende teenwoordigheid in die erediens. Saam met die herinnering wat in die liturgie geskied, gaan die hoop gepaard. Die hoop hou verband met die beloftes van God soos dit in die Skrif vir ons gegee word. Die gemeente leef in vertroue op die Heer en glo vas in sy beloftes in die Skrif. In herinnering en hoop, deur die werk van die Gees, word die beloftes in die Woord lewend vir die gemeente (vgl. Vos \& Pieterse, 1997:92104).

Die bron en krag van die prediking lê in die theologia crucis volgens die verstaan van Luther (Hiebsch \& Van Wijngaarden, 2007:92-103; Cilliers, 2004:53-54). Die prediker wat die gesigspunt van die kruis kies, word met bewondering vir God vervul en word oortuig dat ons nie in die eerste plek die Skrif lees nie, maar die Skrif óns in die eerste plek lees (De Klerk \& De Wet, 2008:74). Ons moet egter nie die Christologie en die Pneumatologie los van mekaar dink nie. Net so kan ons Woord en Gees nie los van mekaar dink nie. Ons benader die teks vanuit ons eie kulturele, ekonomiese, politieke en religieuse situasie met die oog daarop om ook die kulturele, sosiale, ekonomiese, politieke en religieuse konteks van die teks te ondersoek en te verstaan. Wanneer hierdie twee kontekste (teks en huidige konteks) op mekaar biddend en mediterend betrek word, is die lewende werking van die Gees en die Woord medebepalend vir die boodskap van die preek. Met hierdie belydenis van die werking van God deur sy Gees en Woord, vertrou die prediker dat sy inspanning met getroue eksegese en inlewing in die situasie van die gemeente sal uitloop op die prediking van die lewende Woord van God.

Die ondersoekers se preekanalitiese modelle wat vervolgens aan die bod kom, deel almal die reformatoriese benadering tot die prediking. Die ondersoeke van Cilliers (1982), Pieterse (1986; 1995a; 1995b), Moehn (1996), Vaessen (1997), Stark (2005). De Klerk et al. (2009) en die model van Immink \& Verweij (2007) is hier ter sprake.

\section{Verskillende modelle vir inhoudsanalise van preke}

\subsection{Die linguisties-teologiese, deduktiewe model van inhoudsanalise vir preke (Cilliers, 1982)}

Die eerste werk op die gebied van preekanalises in ons land is deur Johan Cilliers gedoen (Cilliers, 1982; vgl. ook Cilliers, 1996). Sy vraagstelling gaan oor die vasstelling van die "voetspore" van die Gees in die taal van die preek (Cilliers, 1982:5). Sy ondersoek han- 
del oor die vraag of daar in die taalstrukture van die preek ruimte gelaat of geopen is vir die genade, vir die primaat van God se werk in ons wanneer sy Woord in die gemeente en die wêreld uitgeroep word (Cilliers, 1982:7, 8). Die uitgangspunt van hierdie vraagstelling is die teologiese begrip van Rudolf Bohren, in aansluiting by A.A. van Ruler, naamlik die Theonome Reziprozität - die werk van ons en die Gees tesame, waarin die Gees die inisiatief en die primaat het (Cilliers, 1982:7; vgl. Bohren, 1974:76). Hy is in sy preekanalise op soek na die grammatika van die Gees. Binne die teks as weefstuk van woorde, weef die Gees sy spraakpatrone, kan sy leidraad opgespoor word. Cilliers soek na 'n pneumatologiese retoriek (Cilliers, 1982:5). Met hierdie vraagstelling en doel voor oë kies hy die model van preekanalise wat as die Heidelbergse model bekend staan en in die Bohren-kring ontwikkel is. Gerd Debus het hierin 'n rol gespeel (Cilliers, 1982:33) en die beskrywing van die model het later in boekvorm verskyn (vgl. Bohren \& Jörns, 1989).

Die preekpraktyk word ondersoek met 'n kwalitatiewe praktykanalise op 'n teologies-deduktiewe wyse. Die ondersoekmodel is deduktief verbonde aan 'n voorafgaande teologiese teorie en kwalitatief in die opset van die analise. Cilliers werk met 'n viervoudige vraagstelling aan die preekteks (Cilliers, 1982:36-38).

- Die Naam: Heilig die prediker die Naam (van God)? Word 'n wettiese evangelie, 'n wettiese wet, 'n kombinasie van albei, of die eenheid van wet en evangelie verkondig? Is die prediker 'n getuie van die teenwoordigheid van God?

- Die Bybelteks: 'n Preek is die uitspreek van die Bybelteks. Honoreer die prediker die konteks van die teks? Bly hy getrou aan die taalstruktuur en tydsvorm van die teks en word die performatiewe krag van die teks en die teenwoordigheid van God vandag uitgespreek?

- Die gemeente: Het die prediker begrip vir die diepere relasie tussen God, Bybelteks en gemeente? Word die gemeente as volwaardige volk van God of as onvolwasse opponent benader? Word die gemeente in die teenwoordigheid van God geplaas, waarop hulle "amen" kan sê op die Woord?

- Die prediker: Die prediker stel homself, bewus of onbewus, in sy prediking voor. Vereenselwig hy hom met die gemeente, of distansieer hy homself? Is sy intensie selfgesentreerd of in diens van die heiliging van die Naam? Wat is sy relasie tot die Bybel- 
teks? Stel hy eise aan die gemeente wat hyself nie kan uitvoer nie?

Cilliers het twee preke oor dieselfde teks, Psalm 1, van Duitse predikers analiseer (Von Rad en Bohren), en twee Suid-Afrikaanse preke, van Boesak en A.P. Treurnicht. Hy ontwikkel dan 'n pneumatologiese retoriek (Cilliers, 1982:171-194) en verfyn die preekanalitiese model, wat met 'n teologiese raamwerk as maatstok werk waarna in die preke gesoek word.

\section{2 'n Kwalitatief-kwantitatief, deduktiewe model van inhoudsanalise van preke (Pieterse, 1986)}

Pieterse $(1986 ; 1995 b)$ het inhoudsanalise gedoen op 105 preke in 'n eerste fase van kwalitatiewe analise aan die hand van 'n preekteorie en daarna met 'n kwantitatiewe statistiese ondersoek op die resultaat van die kwalitatiewe inhoudsanalise. Ons sou dit 'n kwalitatief-kwantitatiewe praktykanalise op 'n teologiese-deduktiewe wyse kon noem. Ook hier is 'n teologiese teorie in die preekanalise op die materiaal getoets met 'n kwalitatiewe en kwantitatiewe opset. Die navorsingsvraag was of daar verskillende preekstyle in die praktyk kan wees as die preke bevra word met 'n hermeneutiese teorie vir die homiletiek. Die hermeneutiese teorie werk met twee kontekste, naamlik die konteks van die prediker en die gemeente en die konteks van die Skrifteks (vgl. Pieterse, 1979). Die ondersoek is gerig deur 'n werkshipotese wat vermoed dat daar aan die hand van die hermeneutiese teorie drie verskillende preekstyle in die praktyk sal wees. Aan die hand van Max Weber se metode van ideëeltipes is drie preekstyle geabstraheer, naamlik Skrifgeoriënteerd, situasiegeoriënteerd en aktueelgeoriënteerd (Pieterse, 1986:53). Die doel van die ondersoek was om vas te stel of predikante daarin slaag om op 'n hermeneutiese wyse met eksegese en aktualisering van die preek te werk gaan. Op grond van die preekteorie wat die outeur ontwikkel het (Pieterse, 1979), is 'n vraekompleks as 'n skedule opgestel, telkens met twee aspekte, naamlik Skriftuurlikheid en die huidige kontekstualiteit (Pieterse, 1986:58-61). Die predikers is elkeen vir sewe preke gevra en hulle verteenwoordig voorstedelike en middestadgemeentes in Pretoria gedurende 1983-1984.

Hierdie preke is eers op 'n kwalitatiewe wyse ondersoek aan die hand van die vraekompleks in die skedule; daarna is die resultate hiervan op die rekenaar ingevoer en met Chi-kwadraat en variansieontleding getoets, sodat die statistiek die preekstyle in groepe kon identifiseer. Drie preekstyle het inderdaad na vore gekom: 38,1\% van die preke het die aktueelgeoriënteerde styl benader; 31,4\% het 
die Skrifgeoriënteerde styl benader; en $17,1 \%$ die situasiegeoriënteerde styl; $12,4 \%$ was nie klassifiseerbaar nie. Slegs $38,1 \%$ was dus hermeneuties geslaagd volgens die teorie wat gebruik is; en $61,9 \%$ was hermeneuties nie geslaagd nie. Die oorgrote meerderheid van die preke se vorm was teks-tematies. Die navorsingsvraag het die metode bepaal.

\section{3 'n Kwalitatief-induktiewe model van inhoudsanalise van preke (Pieterse, 1995a)}

'n Ander aanpak as om met 'n teorie as teologiese raamwerk preke te analiseer, is dié van 'n induktiewe analise waar uit die preke self vasgestel word wat die prediker sê en so tot temas en daarna tot teorievorming te kom (vgl. Pieterse, 1995a). Hierdie navorsing het twaalf preke van Desmond Tutu geanaliseer, waarvan enkeles toesprake van godsdienstige aard was, wat hy vanaf 1977 tot 1992 profeties in die apartheidstydperk in Suid-Afrika gepreek het. Die vraag was om die teologie vas te stel waarop sy profetiese prediking gebaseer is. Die vraag was verder of sy prediking oor 'n tydperk van vyftien jaar verander het, of geweldsituasies of nie-geweldsituasies ' $n$ invloed gehad het, en of hy verskillend teenoor swart en wit gehore gepreek het.

Die navorsingsvraag van die ondersoek was deurslaggewend in die keuse van 'n induktiewe model van inhoudsanalise volgens die grounded theory-benadering in kwalitatiewe ondersoek (vgl. Glaser \& Strauss, 1967). Die gepubliseerde en geskrewe preke is in 'n rekenaarprogram getik en die Kwalitan-program het die eerste ontleding gedoen (die Kwalitan-program is ontwikkel deur Wester en Peters, vgl. Pieterse, 1995a:112-135). Daarmee kon die sleutelwoorde (trefwoorde) met hulle frekwensies van voorkoms van elke preek en van die totale aantal preke geïdentifiseer word. Die sleutelwoorde alleen toon aan dat die woord God 'n sentrale kategorie in die preke vorm. Met die analise van die preke is kodes aan segmente van gedagte-eenhede van die preek toegeken wat gelei het tot die formulering van temas wat uit die preke na vore kom. Dit het as basis gedien vir die kategorieë wat in die dokumente voorkom. Argumentasiestrukture en teoretiese riglyne kan opgestel word, sodat Tutu se boodskap in terme van die bevrydingsteologie, van sy algemene teologie, die politieke temas, die politieke realiteit, sy boodskap oor politieke verandering en die politieke toekoms van bevryding vasgestel kon word. Die argumentasiestruktuur van elke preek het die retoriese aard van elke preek weergegee. Sy boodskap van vreedsame verandering en 'n nie-rassige samelewing van 
wit en swart wat in vryheid kan ontwikkel, het oor vyftien jaar dieselfde gebly. Sy profetiese prediking dat God die bevryding sou bring, is gebaseer op die kruisteologie. Christus het die kwaad aan die kruis oorwin - daarom kan die kwaad van onderdrukking nie standhou nie en God sal daarvoor sorg wanneer ons volkome op Hom vertrou. Die navorsingsvraag het die model bepaal.

\section{4 'n Induktief-deduktiewe kwalitatiewe model van inhoudsanalise van preke (Moehn, 1996)}

Moehn (1996) het 'n proefskrif geskryf oor sy inhoudsanalise van sewentien van Calvyn se preke, wat hy uit Handelinge 4:1-6:7 in Genève gepreek het van April tot Augustus 1550. Sy navorsingsvraag gaan oor hoe Calvyn die teks en die hoorders op mekaar betrek. Moehn het die Heidelbergse metode gebruik soos dit in die Bohren-kring ontwikkel is. Hy kon gebruik maak van die gepubliseerde werk oor hierdie metode (vgl. Bohren \& Jörns, 1989). Hy kies hierdie model omdat dit met geskrewe of gedrukte preke werk en omdat die metode by die kerklike opleiding in Utrecht gebruik word om preke en gebede te analiseer. Die doel van die ondersoek was om die probleem van die verhouding tussen God en die hoorders van die prediking te hanteer.

Moehn pas die viervoudige komplekse van vrae van die Heidelbergse metode op die preke toe, naamlik die Naam van God, die teks, die hoorders, en die prediker (Moehn, 1996:3-4; vgl. ook Cilliers, 1982, hierbo). Dit beteken dat hy die teoretiese raamwerk op die preke plaas om te kyk in hoe 'n mate dit aan die vrae beantwoord, terwyl die analise op 'n kwalitatiewe wyse geskied. Om goeie uitvoering aan sy ondersoekvraag te kan gee, skets hy die historiese konteks van Genève. Dit behels die konteks van die Reformasie, die persoonlike situasie van Calvyn en die sosiale en politieke situasie van die gemeente in Genève. Hy vertrek in sy analise van 'n sketsmatige teologiese vooronderstelling dat die kennis van God en die kennis van die mens en die onderlinge verhouding van die twee 'n sentrale tema vorm in Calvyn se teologiese ontwerp (Moehn, 1996:6). Indien dit 'n sentrale tema in sy teologiese werk is, veronderstel Moehn dat God en die hoorders ook 'n sentrale plek in sy preke inneem. Hierna het hy op 'n induktiewe wyse te werk gegaan. Die volledige preke van Calvyn is in die rekenaar ingevoer en met behulp van die Kwalitan-program is nagegaan met watter frekwensies bepaalde woorde in die preke voorkom. Dit verskaf sleutelwoorde sonder om dit in die konteks van die preke te plaas. Die sleutelwoorde toon aan dat God en die hoorders 'n 
sentrale kategorie in die preke vorm (Moehn, 1996:7). Daarna is die sinne geselekteer waarin die sleutelwoorde oor God en hoorders voorkom. Die tema "God roep ons tot sy diens" kom uit die analise na vore as die wyse waarop die verhouding tussen God en die hoorders deur Calvyn hanteer word. Daarna volg die analise met die vier vraekomplekse wat hy self as induktief beskryf (Moehn, 1996:382). Tog is dit, volgens my verstaan, 'n teologies-deduktiewe wyse van analise, omdat 'n raamwerk van voorafbepaalde vrae op die preke geplaas word in die bevraging en analise van die preke.

Nadat die analise gedoen is, het hy die stof geïnterpreteer. Die resultate van sy ondersoek is insiggewend. Calvyn het streng by die Skrifteks gehou met deeglike eksegese, ook met inagneming van die historiese konteks van die teks, en die teks aktueel toegepas in die situasie van die gemeente. Moehn se werk het die Heidelbergse metode verder verfyn wanneer 'n mens sleutelwoorde (key words) in die preke identifiseer.

\section{5 'n Kwalitatief-hermeneutiese model van inhoudsanalise van preke (Vaessen, 1997)}

Vaessen beskou die Heidelbergse analisemodel en die kwalitatiefinduktiewe model van Pieterse (1995a) as retoriese analises en dus nie voldoende om onder die retoriese oppervlak van die taal van die preek deur te dring na die interpretasiemodel van die preek nie (Vaessen, 1997:121, 130). Daarom gaan hy sy eie weg na aanleiding van sy vraagstelling en ontwikkel 'n model gebaseer op die tekstuele hermeneutiek van Paul Ricoeur. Sy navorsingsvraag het sy analisemodel bepaal. Dit handel oor die interpretasiemodelle wat predikers gebruik om die teks vir die preek te verstaan (Vaessen, 1997:140). Hy het twintig predikante gevra om oor die boek Rut te preek. Twee-derdes was manlik en een-derde vroulik, komende uit verskeie opleidings, verskillende modaliteite in die Hervormde Kerk in Nederland en van verskillende leeftydsgroepe. Hy het gebruik gemaak van Kwalitan wat die trefwoorde (sleutelwoorde) aandui, sodat die preke in segmente verdeel kon word.

Die trefwoorde is voorsien van kodes wat elkeen 'n sekere interpretasiemodel oor die hermeneuse tussen teks en leser aandui. Die ondersoekvrae is gebou op die verskillende hermeneutiese teorieë wat hy beskryf. Die interpretasiemodelle verskil in dié opsig dat klem óf op die teks gelê word, óf dat klem op die leser gelê word, terwyl Ricoeur 'n dialektiek tussen teks en leser voorstel. Hy het vervolgens die aantal kere wat verskillende interpretasiemodelle in die preke voorkom, getel en uiteindelik 'n "numerieke" beeld in 'n tabel 
opgestel (Vaessen, 1997:190-191). Daarna kon hy 'n totaalbeeld van elke respondent se preke ten opsigte van die interpretasiemodelle opstel. Volgens Ricoeur se hermeneutiese fases van gis, toets-en-verklaar en dan begryp, kon hy die effek van die interpretasiemodelle wat gebruik is op die verstaan van die teks en die hoorders in die preke uitwys.

Hy het sy inhoudsanalises na die respondente gestuur sodat hulle dit kon kontroleer. Gesprekke met hulle het ook plaasgevind indien hulle daartoe bereid was. Dit het hy gedoen omdat die hele analiseproses 'n saak van interpretasie is (Vaessen, 1997:148). Hierdie optrede van Vaessen is volgens my 'n winspunt in die ontwikkeling van die inhoudsanalitiese modelle wanneer hermeneuse getoets moet word.

\section{6 'n Kwalitatiewe toetsing van 'n teorie oor prediking as die Woord van God deur 'n model van inhoudsanalise van preke (Stark, 2005)}

Ciska Stark het 'n uitgebreide teorie as homiletiese model vir die prediking van die Woord van God ontwikkel (Stark, 2005:195-213). Die vraag wat sy ondersoek, het te make met die wyse waarop prediking, deur die werking van die Heilige Gees, as Woord van God verstaan kan word (Stark, 2005:215). Die vraag bepaal die model van preekanalise. Sy het dus uit die bestaande modelle geleer dat preekanalise ' $n$ interpretatiewe metodologie is. Die basiese elemente uit die bestaande modelle, soos hierbo bespreek, het Stark gebruik in 'n interpretatiewe analisemodel om haar teorie in die preke in die praktyk te toets om tot 'n tipologie van preke te kom. Die homiletiese model het ses faktore wat die vrae aan die preke bepaal het. Sy het negentien kerke geselekteer uit die drie kerke wat die Protestantse Kerk van Nederland uitmaak en die predikers gevra om met die Pinksterdiens van 31 Mei 1998 uit die Ekumeniese Leesrooster te preek en die preke vir analise beskikbaar te stel (Stark, 2005:209). Sy het ook nog met vraelyste die hoorders en die predikante getoets oor hulle relasie tot die homiletiese model (Stark, 2005: 219-226). Wat hier van belang is, is die preekanalisemodel.

Stark het die preekmateriaal in seksies ingedeel. Elke nuwe gedagte, nuwe tema of nuwe uitwerking van 'n tema, vorm 'n nuwe seksie. Elke seksie is voorsien van sleutelwoorde wat die tema van die seksie kenmerk soos dit uit die preek na vore kom. Met die ses faktore van die homiletiese teorie en bybehorende vrae as maatstaf, is die materiaal nader geanaliseer en beskryf (Stark, 2005:215). Uit 
die resultate het sy preke in 'n preektipologie ingedeel. Van die belangrikste resultate is dat mense vandag ook kerk toe kom om God te ontmoet. Hulle sien die preek as belangrik en soek na 'n sfeer van transendensie. Die prediking bied oor die algemeen dit waarna hulle soek. Prediking wat die Woord van God dra, is in die tradisie van die Reformasie steeds uiters belangrik. Preekanalise kan dus as 'n toetsing van 'n homiletiese teorie gebruik word.

\section{7 'n Kwalitatief-deduktiewe gekombineerde model van inhoudsanalise van preke (De Klerk et al., 2009)}

In die vorige patriargale samelewing in wit en swart Suid-Afrikaanse gemeenskappe het predikers 'n haas onaantasbare outoriteit gehad. In die nuwe, demokratiese samelewing van gelyke regte, het predikers kwesbaar geword, omdat die magstrukture verander het. Ook die gemeentelede het as gevolg van die veranderings en die nuwe sosiale probleme in die land kwesbaar geword. Die ondersoekvraag lui: In watter opsig bepaal die prediker se relasie met die Bybelse teks en sy relasie met die hoorders in hulle gemeenskaplike kwesbaarheid, die mate waarin sy kwesbaarheid oorgegee word in geloof aan Jesus Christus, die ware bron van outoriteit en bevrydende krag?

Nadat hulle 'n preekteorie ontwerp het met 'n pneumatologiese kenmerk vir die nuwe tyd (vgl. De Klerk \& De Wet, 2008:71-82), het die outeurs drie predikers van die Gereformeerde Kerke (twee wit en een swart) gevra om aan die empiriese ondersoek deel te neem. Elkeen is gevra vir twee preke, een uit die vorige bedeling in die begin van die negentigerjare, en een uit die onlangse verlede met die oog op preekanalise. Onderhoude is ook met hulle gevoer om hulle persepsies oor hulle preke vas te stel. Met die oog op hulle vraag en ondersoek het hulle die model van Ciska Stark en die Heidelbergse model gekombineer wat aan hulle vraekomplekse kon verskaf waarmee hulle die preke op 'n deduktiewe wyse kon analiseer. Die resultate van die analise het hulle in staat gestel om riglyne vir 'n preekteorie vir die eie tyd te ontwikkel met die oog op 'n nuwe praksis (De Klerk et al., 2009). Weereens het hulle navorsingsvraag die analisemodel bepaal.

\section{8 'n Kwalitatief-induktiewe model van inhoudsanalise van preke (Immink \& Verweij, 2007)}

Die sentrale navorsingsvraag, naamlik: How do ministers deal homiletically during Lent and Holy week with the suffering and death of Jesus in the context of human life and suffering? stuur die 
ondersoek van Verweij in die rigting van die analise van getikte preke volgens die grounded theory-benadering, waarin 'n teorie ontwikkel word vanuit die data uit die preekpraktyk (Immink \& Verweij, 2007:146; vgl. Glaser \& Strauss, 1967; Wester, 1995). Hy maak gebruik van 'n voorlopige teologiese teorie waarin hy die verskillende sienings oor Jesus se lyding en die lyding van mense in konsepte uiteensit wat kan dien as beginbegrippe (sensitising concepts) vir die analise van preke (Immink \& Verweij, 2007:148). Verweij het 36 preke van twaalf verskillende predikers versamel en geanaliseer met die grounded theory-benadering volgens Glaser (1978) se interpretasie daarvan. Wanneer die analise toegepas word, word nuwe konsepte in die data gevind wat die beginbegrippe vervang. Die analise verloop in drie stappe, naamlik dataversameling en die ope kodering deur die preke in segmente te verdeel en kodes aan die segmente toe te ken, die ontwikkeling van kategorieë en hulle eienskappe deur die voortdurende vergelyking van kodes gebaseer op segmente van die preke met argumentasie in die refleksie op die materiaal, en die ontwikkeling van 'n gegronde teorie vir die praktyk soos dit uit die data na vore kom en waarin die vooropige teologiese teorie 'n rol speel (Immink \& Verweij, 2007: 147-149).

Dit is teologiese werk. Die metode funksioneer binne die fundamenteel-teologiese benadering vir die praktiese teologie wat Immink ontwikkel het (Immink, 2003). Alhoewel metodes van die empiriese wetenskappe gebruik word, is die substansiële terrein waarin ondersoek na die prediking plaasvind, 'n godsdienstige praktyk. Die preek geskied in die erediens waarin taalgebruik en ritueel die kenmerke is en waarin die gemeente met 'n oop gemoed in die woorde van die preek en die ritueel van die liturgie God ontmoet (Immink\& Verweij, 2007:141-146; Immink \& Pleizier, 2005:80-85). Hierdie godsdienstige gebeure is die bron waaruit die data vir analise voortkom. Daarom is die konsepte wat gegenereer word en die gegronde teorie vir die praktyk homileties-teologies gestempel. Die analiseproses verloop in der waarheid as 'n voortdurende beweging tussen teologiese teorie en praktyk - eie aan die abduktiewe wyse van die beoefening van die praktiese teologie.

\section{4. 'n Model wat pas by die huidige ondersoek}

Die ondersoeke wat hierbo behandel is, het almal analisemodelle gekies wat gepas het op hulle ondersoekvraag. Die Heidelbergse model is verryk deur die gebruikmaking van die Kwalitan, wat gehelp het om trefwoorde (sleutelwoorde) vas te stel en temas uit segmente 
uit te lig. Die kombinasie van die Heidelbergse model met die model van Ciska Stark deur De Klerk, De Wet en Letšosa het albei modelle verryk en versterk. Die navorsingsvraag van my huidige ondersoek dwing my egter in ' $n$ ander rigting. Uit die analises van Calvyn se preke het dit geblyk hoe sterk die konteks van die armoedige vlugtelinggemeente in Genève daarin funksioneer. Calvyn het klem gelê op omgee vir mekaar en die diakonale en die missionêre taak van die gemeente (Moehn, 1996:357, 383). Ek is nuuskierig om uit te vind of hierdie belangrike aspek van ons gereformeerde teologie in die lig van Jesus se koninkryksgelykenisse in die preke ter sprake kom in ons konteks van armoede. Daarvoor het ek 'n kwalitatiefinduktiewe model nodig soos dit in die Utrecht-kring, veral deur Immink en Verweij, ontwikkel is.

Die leidende navorsingsvraag van hierdie ondersoek is naamlik hoe predikers hulle prediking oor armoede en aan armes as hoorders hanteer met die koninkryksgelykenisse van Jesus as preekteks. Ons weet weinig wat predikers oor hierdie saak sê en hoe hulle die Bybelse tekste en die armoedeprobleem in die preke hanteer. My beplanning is om sulke preke te versamel van predikers in swart, bruin en wit gemeentes in kontekste van armoede en van meer welaf-gemeentes binne die NG kerkfamilie (Verenigende Gereformeerde Kerk en die Nederduitse Gereformeerde Kerk). Die projek sal DV oor die volgende vier jaar gedoen word binne die struktuur van die National Research Foundation. Verweij se aanpak met die drie stappe van analise volgens die grounded theory-benadering pas die beste op my navorsingsvraag. Die navorsingsvraag, dit is die argument van die artikel, het my tot hierdie model gelei.

\section{Geraagpleegde bronne}

BOHREN, R. 1974. Predigtlehre. München: Verlag.

BOHREN, R. \& JÖRNS, K-P. 1989. Die Predigtanalyse als Weg zur Predigt. Tübingen: Francke.

CILLIERS, J.H. 1982. Soos woorde van God: ontwerp van 'n preekanalitiese model. Stellenbosch: Universiteit van Stellenbosch. (D.Th.-proefskrif.)

CILLIERS, J.H. 1994. Fides quaerens imaginem: estetika as uitbeelding van die publieke kerk: liturgie op soek na beelde. Praktiese teologie in Suid-Afrika, 19(1):1-18.

CILLIERS, J. 1996. Die uitwissing van God op die kansel: ontstellende bevindings oor Suid-Afrikaanse prediking. Kaapstad: Lux Verbi.

CILLIERS, J. 2004. Die lewende stem van die evangelie: nuut gedink oor die basiese beginsels van die prediking. Stellenbosch: Sun Media.

DE KLERK, B.J. 2007. Basisteoretiese grondslae van die seën in die erediens en voortvloeiende riglyne vir die liturgie. In die Skriflig, 41(3):391-413. 
DE KLERK, B.J. \& DE WET, F.W. 2008. Preacher on the edge: exposure to vulnerability as a new opportunity in preaching the righteousness of the kingdom of God to vulnerable listeners. Practical theology in South Africa, 23(2):62-84.

DE KLERK, B.J., DE WET, F.W. \& LETŠOSA, R.S. 2009. Exposure to vulnerability as a new opportunity in preaching the gospel to vulnerable people. Practical theology in South Africa, 24. (To be published.)

DE KLERK, B.J. \& JANSE VAN RENSBURG, J.J. 2005. Preekgeboorte: 'n handleiding vir gereformeerde eksegese en prediking. Toegepas op 1 Petrus 2:11-12, 18-25. Potchefstroom: Potchefstroomse Teologiese Publikasies.

GLASER, B.G. 1978. Theoretical sensitivity: advances in the methodology of grounded theory. Mill Valley: Sociology Press.

GLASER, B.G. \& STRAUSS, A.L. 1967. The discovery of grounded theory: a basic strategy underlying qualitative research. Chicago: Aldine.

GRÖZINGER, A. 2008. Homiletik. Gütersloh: Gütersloher Verlagshaus.

HIEBSCH, S. \& VAN WIJNGAARDEN, M., red. 2007. Martin Luther: zijn leven, zijn werk. Kampen: Kok.

IMMINK, F.G. 2003. In God geloven: een praktisch-theologiese reconstructie. Zoetermeer: Meinema.

IMMINK, F.G. \& PLEIZIER, T. 2005. Research in homiletics. (In Grözinger, A. \& Kong Ho Soon, eds. Preaching as shaping experience in a world of conflict. Singapor: Gospel works. p. 80-89.)

IMMINK, F.G. \& VERWEIJ, A. 2007. Dealing with the suffering of Jesus in the context of a suffering world: an example of empirical homiletics. (In Vos, C.J.A., Hogan, L.L. \& Cilliers, J.H., eds. Preaching as a language of hope. Pretoria: Protea Book House. p. 141-154.)

KELLE, U. 2005. "Emergence" vs. "Forcing" of empirical data? A crucial problem of "Grounded theory" reconsidered. FGS forum: qualitative social research, 6(2): Art. 27.

MOEHN, W.H. Th. 1996. God roept ons tot zijn dienst: een homiletisch onderzoek naar de verhouding tussen God en hoorder in Calvijns preken over Handelingen 4:1-6:7. Kampen: Kok.

PIETERSE, H.J.C. 1979. Skrifverstaan en prediking. Pretoria: NG Kerkboekhandel.

PIETERSE, H.J.C. 1986. Verwoording en prediking. Pretoria: NG Kerkboekhandel.

PIETERSE, H.J.C., ed. 1995a. Desmond Tutu's message: a qualitative analysis. Kampen: Kok.

PIETERSE. H.J.C. 1995b. Second impression: communicative preaching. Pretoria: Unisa.

PIETERSE, H.J.C. 2009. Prediking oor die koninkryk van God: 'n uitdaging in 'n nuwe konteks van armoede. HTS teologiese studies/HTS theological studies, 65(1):1-7.

STARK, C. 2005. Proeven van de preek: een praktisch-theologisch onderzoek naar de preek als Woord van God. Zoetermeer: Boekencentrum.

VAESSEN, J. CHR. 1997. Tussen Schrift en preek: ontwerp van 'n analysemodel voor de Bijbelinterpretatie in preken met gebruikmaking van de tekstuele hermeneutiek van Paul Ricoeur. Kampen: Kok.

VOS, C.J.A. \& PIETERSE, H.J.C. 1997. Hoe lieflik is U woning. Pretoria: RGN. 
WESTER, F.1995. Strategieën voor kwalitatief onderzoek. 3e druk. Bussum: Countinho.

\section{Kernbegrippe:}

inhoudsanalise van preke: armoede modelle: inhoudsanalise van preke navorsingsvraag: bepaal keuse van model

\section{Key concepts:}

content analysis of sermons: poverty models: content analysis of sermons research question: determines choice of model 